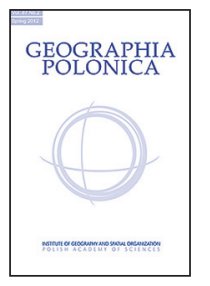

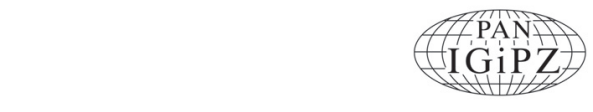

INSTITUTE OF GEOGRAPHY AND SPATIAL ORGANIZATION POLISH ACADEMY OF SCIENCES www.igipz.pan.pl

www.geographiapolonica.pl

\title{
THE IMPACT OF POPULATION POTENTIAL ON POPULATION REDISTRIBUTION IN THE LONG-TERM HISTORICAL CONTEXT: CASE STUDY OF REGION STREDNÉ POVAŽIE, SLOVAK REPUBLIC
}

\author{
Michal Klobučník • Lucia Máliková \\ Department of Human Geography and Demography \\ Comenius University in Bratislava \\ Ilkovičova 6, Mlynská dolina, 84215 Bratislava: Slovakia \\ e-mails: klobucnik@fns.uniba.sk・malikova@fns.uniba.sk
}

\begin{abstract}
Interaction potential represents a significant phenomenon affecting economic, political and social sphere to a large extent. One of the possible interaction potential is population potential which is the object of our study. The purpose of this article is to analyse population potential and its impact on population redistribution in the long-term historical context. We point out some implications in the changing nature of population potential in the last 50 years as well as insight into its future trajectory. Research focuses on Stredné Považie, one of the traditional industrial regions in Slovakia, where population potential is molded by this historical orientation.
\end{abstract}

\section{Key words}

population potential $\bullet$ spatial interactions $\bullet$ region Stredné Považie $\bullet$ accessibility • distance

\section{Introduction}

In current globalized society, interactions play an important part, or even a necessary condition, in day to day practices of individuals as well as the whole society, and across all hierarchical levels, from local to international. Thus, interaction potential represents a significant phenomenon affecting economic, political and social sphere to a large extent. All of these interactions happen in space, whether it is virtual or real world, and because of that geography can be seen as the most relevant discipline in the study of different types of spatial interactions, their organization and broader implication in society.

The concept of spatial interaction was in geographical society introduced by American geographer Edward L. Ullman in 1954 as general denotation for the various forms of movement of people, goods and information between certain spatial units. Thus, the 
interaction potential expresses the opportunity to interact, in other words it means possible (potential) interaction of one zone with all other zones of the system (Bezák 2011). However, interaction potential is quite distinct from and should not be confused with 'potential' in terms of the sense of capacity for something (Rich 1980), for instance as development potential (Binek et al. 2007), but rather perceived as a capacity of something, for instance economic, human, environmental potential of a certain area.

Extremely important role in terms of spatial interaction plays a factor of distance. It is distance between zones of interaction that acts as a barrier to a certain extent. It means that with increasing distance the intensity and amount of interaction is generally decreasing. Therefore we can describe it as impedance, fractional or braking effect of distance on interaction (Bezák 2011). In accordance with the above mentioned statement, argument of American geographer W.R. Tobler, specialized in the field of quantitative spatial analysis, was implemented into geography as the first law of geography - "Everything is related to everything else, but near things are more related than distant things" (Tobler 1970: 236). At the same time, it cannot be neglected that with the modernization processes and rapid development telecommunication technologies, the perception of geometric aspects is shifting from looking through the distance of an area to its accessibility (Jerábek et al. 2004). In this context, accessibility can be simply understood as the possibility of reaching the places or services from another places, which can be measured for example by distance or travel expenses or time required for a journey (Clark 1990). Therefore we can say, that accessibility summarizes the relative opportunity for interaction (Goodall 1987). Condeço-Melhorado et al. (2014) add that there is no doubt that spatial interaction is related to accessibility, since improved accessibility will increase the spatial interaction between places. Daily commuting to work, school, shopping and services still remains under influence of both, distance and accessibility, unless we include possibility of online education, internet shopping or employment in so called footloose industries, where distance recedes into the background. Moreover, when discussing population potential, the related concept of accessibility can be useful in planning the optimum location for such services and thus help to retain population in the certain area (Pacione 2014).

One type of interaction potential is a population or demographic potential. This model was introduced by J.Q. Stewart (1941, 1942), American physicist and proponent of social physics, who has also enriched geography of the gravity model (Bezák 2011). Both, potential and gravity model, have close conceptual, empirical and historical associations. However, whereas the gravity model is concerned with analysis and prediction of an observed pattern of spatial flows, the potential model focuses more on the opportunity for interaction between groups, created by their size and location rather than with the interaction itself (Rich 1980). In other words, population potential sums up the total influence of the whole structure of population settlements weighed by the inverse of the relative distance (Faína \& López-Rodríguez 2006).We can intuitively understand the concept of population potential as a measure of the demand potential that the whole population exerts over every location within a given geographical space (Faína \& López-Rodríguez 2003).

And it is population potential which is the object of our study. Although, in our analysis we draw on earlier studies and processing of the theoretical basis of this concept, reaching back to early 1940s, we attempt to provide its effective application also with reflection on the current proceedings of the authors. These authors refer on interaction models, and especially population model, in terms of theoretical discourses (Rusnák et al. 2014), within EU discourses (Faíña \& López-Rodríguez 2003, 2006) or as an application to various cases on present reality and future estimates (Ediev 2001; Vaňo 2014).

Specifically, the purpose of this article is to point out the impact of the population potential on population redistribution in the 
region Stredné Považie (Slovak Republic). We focus on long-term development of this phenomenon, evaluating the changes in population potential over the last 50 years while at the same time providing an overall view of the territorial structure of the population potential and population redistribution within a given geographical space. However, we attempt to provide insight not only to the former situation in the past, but also to outline possible trends in the upcoming years, with the projection of population potential to 2021, which is generally based on the reflection of past and current trends into the future (Vystoupil 2003). At the same time, we point out some implications and key features in the changing nature of population potential in the selected case study region. Despite the fact that our analysis builds on a model based on the gravity forces, we acknowledge the role of other than gravity factors that influence patterns of population distribution and potential in a specific area, and thus should not be neglected. We presuppose that these factors arising from the specifics of the region itself might differentiate redistribution of population potential across the regions.

\section{Methodology applied}

Already at the very end of the 1970s, Rich (1980) emphasized that it was the human geography literature where the potential model has appeared the most frequently, especially as an index of the intensity of possible interaction between specific groups at different locations. Different application of population potential was demonstrated also in latter work by Michniak (2002), where he points out significant position of accessibility in this context. Thus, utility of population potential extends for example to study of correlation between accessibility and another variables; impact that changing character of the borders has on accessibility (Gutiérrez 2001); impact of changing urban systems on its accessibility (Linneker \& Spence 1992); study of relationship between accessibility and justice and efficiency in the provision of public services or its role in determining accessibility and relative position (location) in regional development (Keeble et al. 1982; Geertman \& Ritsema Van Eck 1995). Last but not least, population potential can be interpreted as accessibility rate within another models, e.g. as attractiveness of place within the model of spatial interactions (Pooler 1987).

Based on the former variation, Rich (1980) also claims that although all applications of the potential model share the same background, different versions of potential models vary in three main ways: in their interpretation; in the phenomena dealt with; and in the reasons for using them. In our context, we work with the interpretation of this model in terms of 'influence' of the population potential on population redistribution, thus we attempt to connect it with a variety of social, economic and demographic phenomena and demonstrate broader spatial implications.

\section{Delimitation of case study area}

Stewart and Warntz (1958) saw the status and progress of geographical research as being reduced by its concentration until that time on 'microscopic' studies of individual areas case studies (in Rich 1980). Emanating from their latter shift to 'macroscopic' approach resulting in a greater level of abstraction and generalization, we acknowledge that it is really the case study approach that serves as a mean of securing greater understanding of the processes operating to determine spatial relationships (ibid.).

Our case study is represented by the region Stredné Považie, one of the traditional industrial regions in Slovakia, where population potential is molded by this historical orientation (Fig. 1). Region comprises 5 adjacent administrative units - districts situated along the Czech Republic-Slovakia border, with $141 \mathrm{mu}$ nicipalities. Emanating from its geographical position in the borderland, this region could be considered as peripheral (Máliková et al. 2015), however, thanks to its long-term historical development and industrial tradition in engineering (built during the socialism) has 


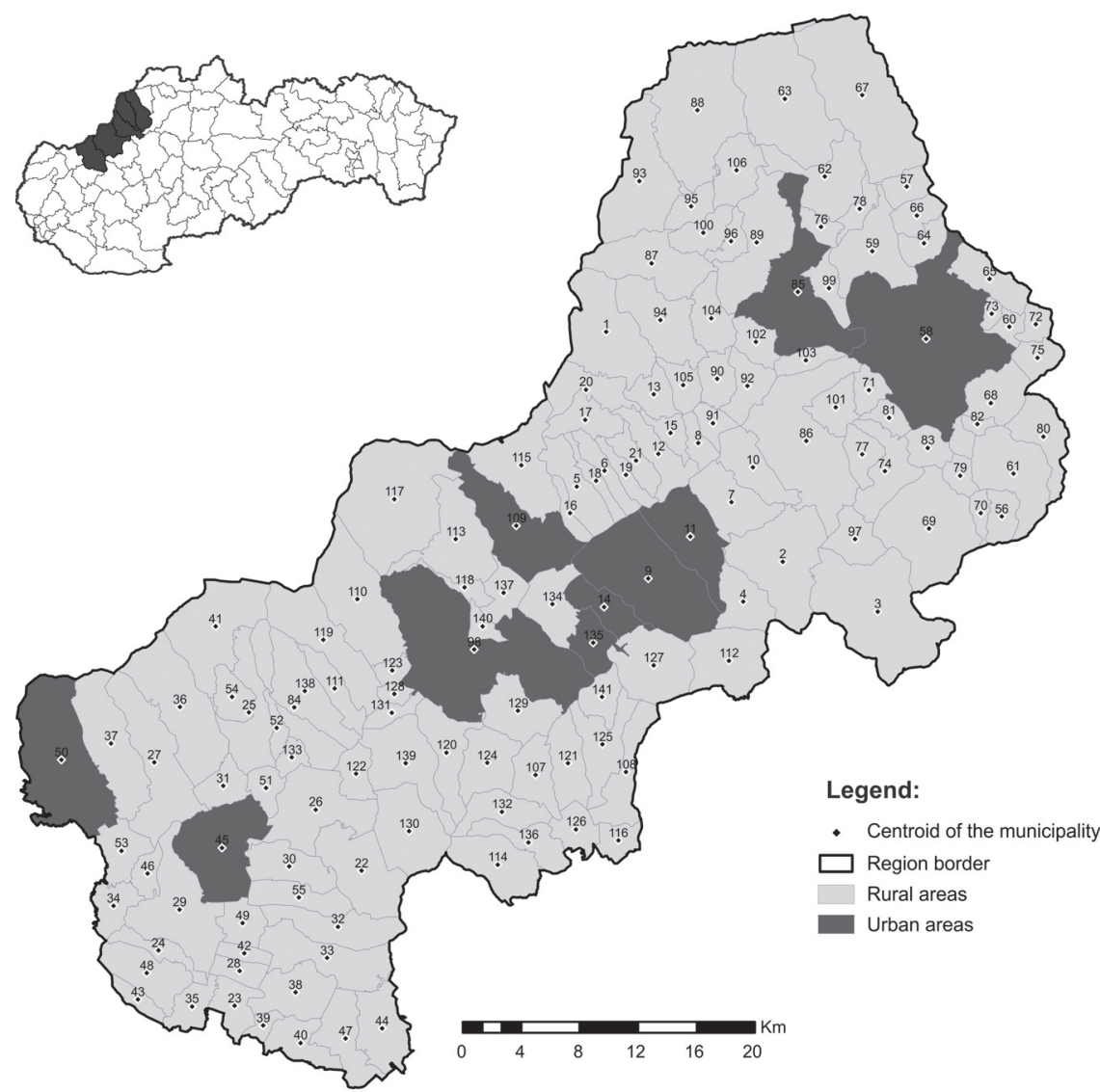

Municipalities in region

$\begin{array}{ll}1 & \text { Červený Kameñ } \\ 2 & \text { Košecké Podhradie } \\ 3 & \text { Zliechov } \\ 4 & \text { Horná Poruba } \\ 5 & \text { Bolešov } \\ 6 & \text { Slavnica } \\ 7 & \text { Košeca } \\ 8 & \text { Dulov } \\ 9 & \text { Dubnica nad Váhom } \\ 10 & \text { Ladce } \\ 11 & \text { Ilava } \\ 12 & \text { Pruské } \\ 13 & \text { Mikušovce } \\ 14 & \text { Nová Dubnica } \\ 15 & \text { Tuchyña } \\ 16 & \text { Borčice } \\ 17 & \text { Krivoklát } \\ 18 & \text { Kameničany } \\ 19 & \text { Sedmerovec } \\ 20 & \text { Vršatské Podhradie } \\ 21 & \text { Bohunice } \\ 22 & \text { Kálnica } \\ 23 & \text { Horná Streda } \\ 24 & \text { Častkovce } \\ 25 & \text { Bošáca } \\ 26 & \text { Beckov } \\ 27 & \text { Bzince pod Javorinou } \\ 28 & \text { Brunovce } \\ 29 & \text { Čachtice } \\ 30 & \text { Kočovce } \\ & \end{array}$

31 Dolné Srnie
32 Hôrka nad Váhom
33 Hrádok
34 Hrachovište
35 Pobedim
36 Moravské Lieskové
37 Lubina
38 Lúka
39 Modrovka
40 Modrová
41 Nová Bošáca
42 Potvorice
43 Očkov
44 Nová Lehota
45 Nové Mesto nad Váhom
46 Višñové
47 Stará Lehota
48 Podolie
49 Považany
50 Stará Turá
51 Trenčianske Bohuslavice
52 Haluzice
53 Vadovce
54 Zemianske Podhradie
55 Nová Ves nad Váhom
56 Sádočné
57 Brvnište
58 Považská Bystrica
59 Udiča
60 Kostolec

61 Domaniža

62 Dolná Marikovà

63 Horná Mariková

64 Jasenica

65 Plevník - Drienové

66 Stupné

67 Papradno

68 Prečin

69 Pružina

70 Čelkova Lehota

71 Sverepec

72 Vrchteplá

73 Záskalie

74 Dolný Lieskov

75 Bodiná

76 Klieština

77 Slopná

78 Hatné

79 Ďurdové

80 Malé Lednice

81 Horný Lieskov

82 Počarová

83 Podskalie

84 Ivanovce

85 Púchov

86 Beluša

87 Zubák

88 Lazy pod Makytou

89 Dohñany

90 Dolná Breznica
91 Horovce

92 Lednické Rovne

93 Lysá pod Makytou

94 Lednica

95 Lúky

96 Mestečko

97 Mojtín

98 Trenčin

99 Nimnica

100 Záriečie

101 Visolaje

102 Streženice

103 Dolné Kočkovce

104 Horná Breznica

105 Kvašov

106 Vydrná

107 Trenčianske Mitice

108 Bobot

109 Nemšová

110 Drietoma

111 Adamovské Kochanovce

112 Dolná Poruba

113 Dolná Súča

114 Dubodiel

115 Horné Srnie

116 Horňany

117 Horná Súča

118 Hrabovka

119 Chocholná - Velčice

120 Trenčianska Turná
121 Neporadza

122 Krivosúd - Bodovka 123 Kostolná - Záriečie

124 Mníchova Lehota

125 Motešice

126 Svinná

127 Omšenie

128 Opatovce

129 Soblahov

130 Selec

131 Velké Bierovce

132 Trenčianske Jastrabie

133 Štvrtok

134 Trenčianska Teplá

135 Trenčianske Teplice

136 Velká Hradná

137 Skalka nad Váhom

138 Melxice - Lieskon

139 Trenčianske Stankovce

140 Zamarovce

141 Petrova Lehota

Figure 1. Case study area 
been considered as one of the most progressive areas within the country, altogether with Bratislava, Košice and Banská Bystrica thus creating central hubs of regional development in Slovakia (Employment Institute 2015).

For our analysis of the population potential and its impact on population redistribution we choose 50-year long period 1960-2011, covering socialist era, transformation period as well as current modern globalized society, while calculating data for every decades according to available census data. In addition to this, we incorporated a short-term projection of population potential and its development to 2021, revealing an interesting future trajectory of this phenomenon. This short-term prediction emanates from the previous demographic development and takes into account the most probabilistic exponential population growth. Moreover, given that past trends can not be precisely applied to the distant future, this kind of projection is particularly suitable to capture future developments in the shortterm period (usually up to 10 years). In order to determine development from the longer perspective, a complex methods (e.g. long term prognosis) would need to be applied. Unlike short-term projection used in our case, such approach, however, must inevitably consider external influences, taking into account qualitative and quantitative changes as well as the effect of other factors that could influence the changing nature of the population potential (Vystoupil 2003).

\section{Data analysis}

In our analysis, we emanate from Stewart's model for population (demographic) potential, where $U_{j}$ is population potential in zone $j, P_{i}$ is population in zone $j$ and $c_{i j}$ represents distance between two zones $-i$ and $j$.

$$
U_{j}=\sum_{i} \frac{P_{i}}{C_{i j}}
$$

Population potential of one zone (e.g. zone 1 ) is therefore the sum of partial fractions (population of the zone and the respective distance from the zone 1) as well as its own potential (highlighted in gray), since we include also interactions within the zone itself. In other words, the concept of population potential must be understood as a force or attraction which the population center $\left(P_{i}\right)$ would exert on an inhabitant located at the point $(j)$ within the given geographical space and influenced by distance between them $\left(c_{i j}\right)$ discourses (Faíña \& López-Rodríguez 2003).

$$
\begin{gathered}
U_{\text {zone1 }}=\sum_{i} \frac{P_{i}}{C_{i j}}=\frac{P_{\text {zone2 } 2}}{c_{1}}+\frac{P_{\text {zone } 3}}{c_{2}}+\frac{P_{\text {zone4 }}}{c_{3}}+ \\
+\frac{P_{\text {zone5 }}}{c_{4}}+\frac{P_{\text {zone6 }}}{c_{5}}+\frac{P_{\text {zone } 7}}{C_{6}}+\frac{P_{\text {zone1 }}}{C_{\text {zone } 1}}
\end{gathered}
$$

When considering the population potential, we think about the interaction of people moving and travelling via road infrastructure. Therefore, in this context the distance is expressed as a road distance in kilometers. However, one problem occurs when considering the distance within the own potential of the zone itself (zone 1 from the Fig. 2). Since it is not possible to omit distance within the zone, or consider it as zero distance, we chose one of the definitions of inner-zone distances used by Bezák (2011), when inner-zone distance is equal to half of the distance to the nearest of the rest of the zones. As it was highlighted before, distance represents the negative

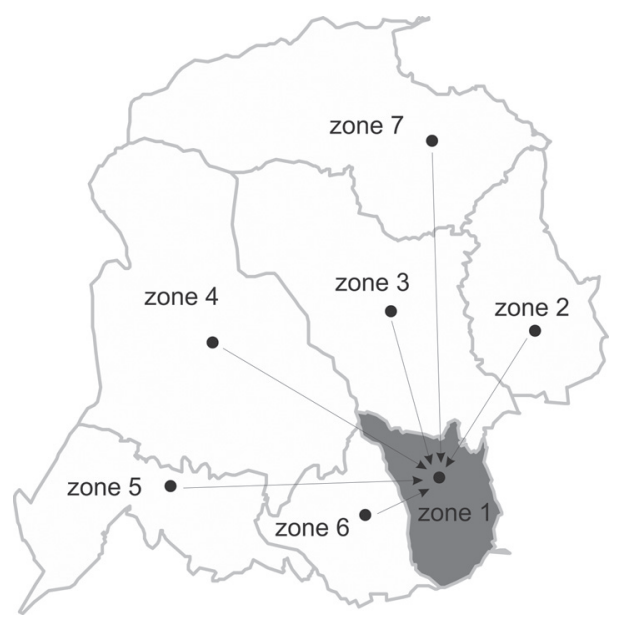

Figure 2. Example of the calculation of population potential of the zone 1 
influence of geographical conditions on the intensity of the interaction in a given time and space (Gregorová \& Kusendová 2005). Emanating from this statement, we assume that within a given geographical space, the population potential will increase with the decreasing distance, which will result in a higher concentration of population in this area.

\section{Empirical results}

Using the above equation (Stewart's model), we calculated the population potential of each of the 141 municipalities in the region. However, it is necessary to point out that in our analysis we consider population potential only within the border of our case study region, thus area adjacent to the region, whether it was another district in Slovakia or crossborder region, was not included. As a result, interactions outside the region were neglected because of the technical difficulty of such analysis in a broader context (with regards to the scope to which these interactions may occur) and potential problems with compatibility of data for Czech Republic. On the one hand proximity of the state border suggests possible transport connections and border crossings that provide new spheres for cross-border interactions. We acknowledge that location in the borderland may actually play a key role in the distribution of population potential, provided that the size of population and the strength of its potential from the opposite side of the border would be significant, since the population potential of every zone is formed by the fractions of population potential of other zones as well as by its own potential. On the other hand, as point out by Halás (2002), this is also determined by the permeability of the border itself with respect to the spatial composition, structure and accessibility of settlements along both sides of the border. Based on the above mentioned presumption we suppose that even inclusion of such interactions would not change situation in our case study region to a larger extent, especially in the neighboring municipalities in the peripheral parts of the region, and it is simply due to physical-geographical factor, mountains, that act as a natural barrier influencing accessibility and thus relating interactions in this area.

Results were processed cartographically in order to provide better overview of spatial distribution of the population potential across the region. Individual map files show basic values of population potential in the analyzed period (Fig. 3), the change of the population potential over the decades (Fig. 4) as well as short-term projection of its possible future trajectory (Fig. 5).

Figure 3 provides a great image of population potential in the region Stredné Považie in the last 50 years. With increasing population in the region, population potential has begun to shape significantly and gradually developed almost continuous line across the central part of the region, where the greatest potential can be recognized. Such a layout emanates from geographical conditions, where central part of the region is located in the valley of the river Vah crossing the entire region, unlike peripheral areas extending into the mountains Biele Karpaty and Javorníky in northern parts and Strážovské vrchy and Považský Inovec in southern parts of the region. Moreover, as it was already mentioned, our case study region is one of the traditional industrial regions in Slovakia, where population potential is molded by this historical orientation. This is also reflected in ascending population potential where industrial tradition is embedded in the place, whether it was at the beginning of the analyzed period when mostly heavy engineering companies and weaponry were established (Mládek 1975), during the economic (as well as industrial) transformation (Mládek 1993), or even in the last years.

At first sight, it might seems that population potential of certain areas has increased rapidly during the last 50 years. Although, there is obvious aggregation of population potential in the central part of the region, we can argue that there was only slight change between the decades from the perspective of individual municipalities (Fig. 4). Looking at the whole region, population potential was increasing till 1980 by almost $10 \%$ during the each decade. 


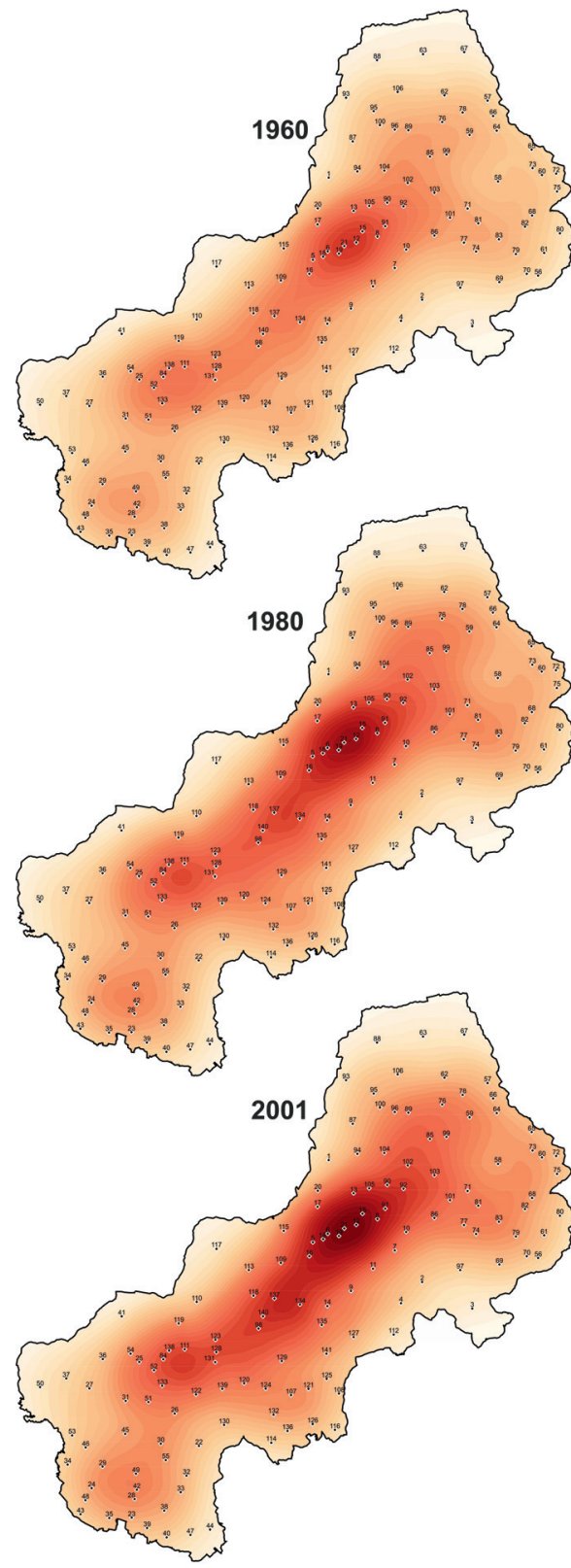

Legend:

- Centroid of the municipality $\square$ Region border

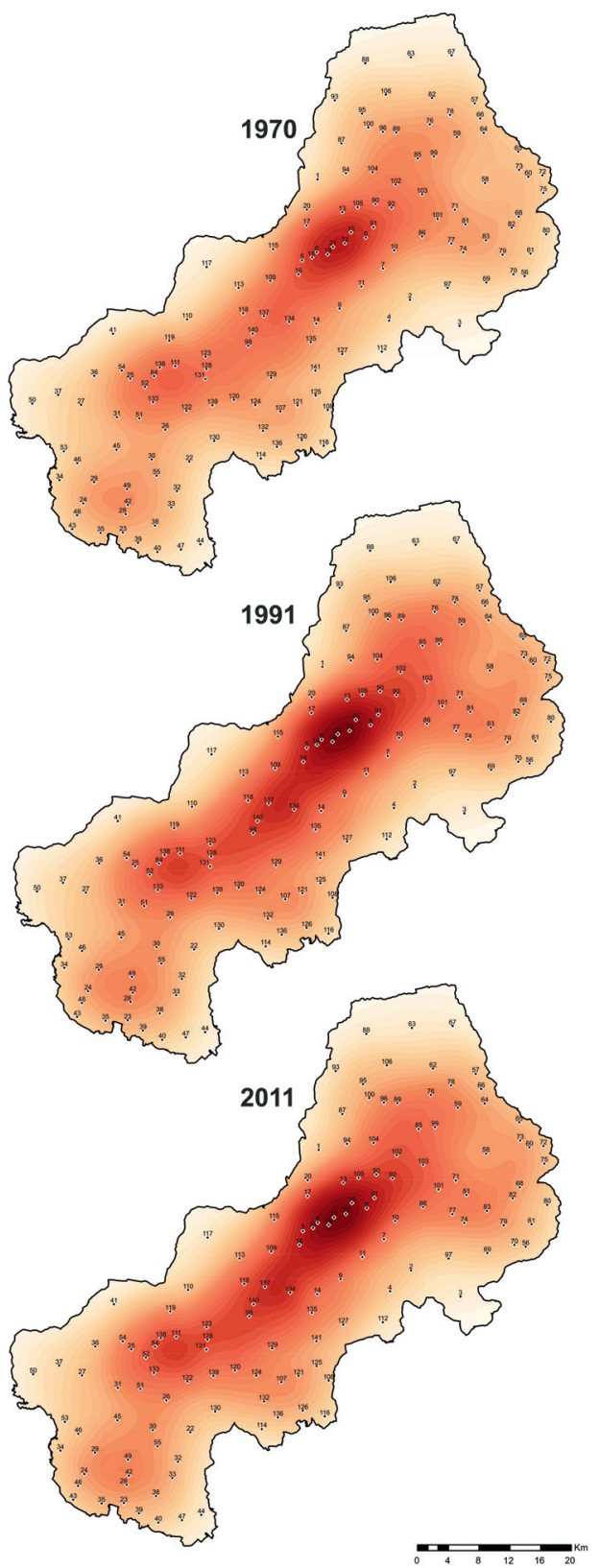

Kernel density (population potential//km²) 45

1883

Figure 3. Population potential in the region Stredné Považie (1960-2011) 


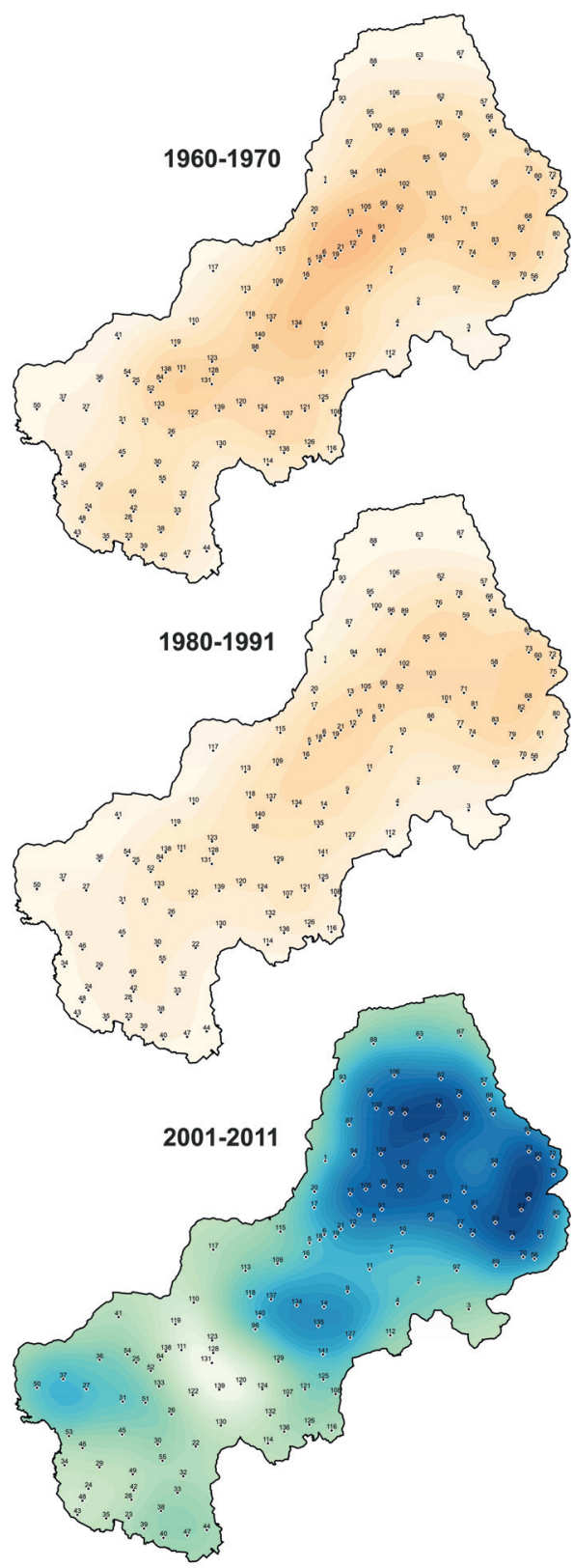

Kernel density (change population potential $/ \mathrm{km}^{2}$ in \%) $-0.12$ 0.03

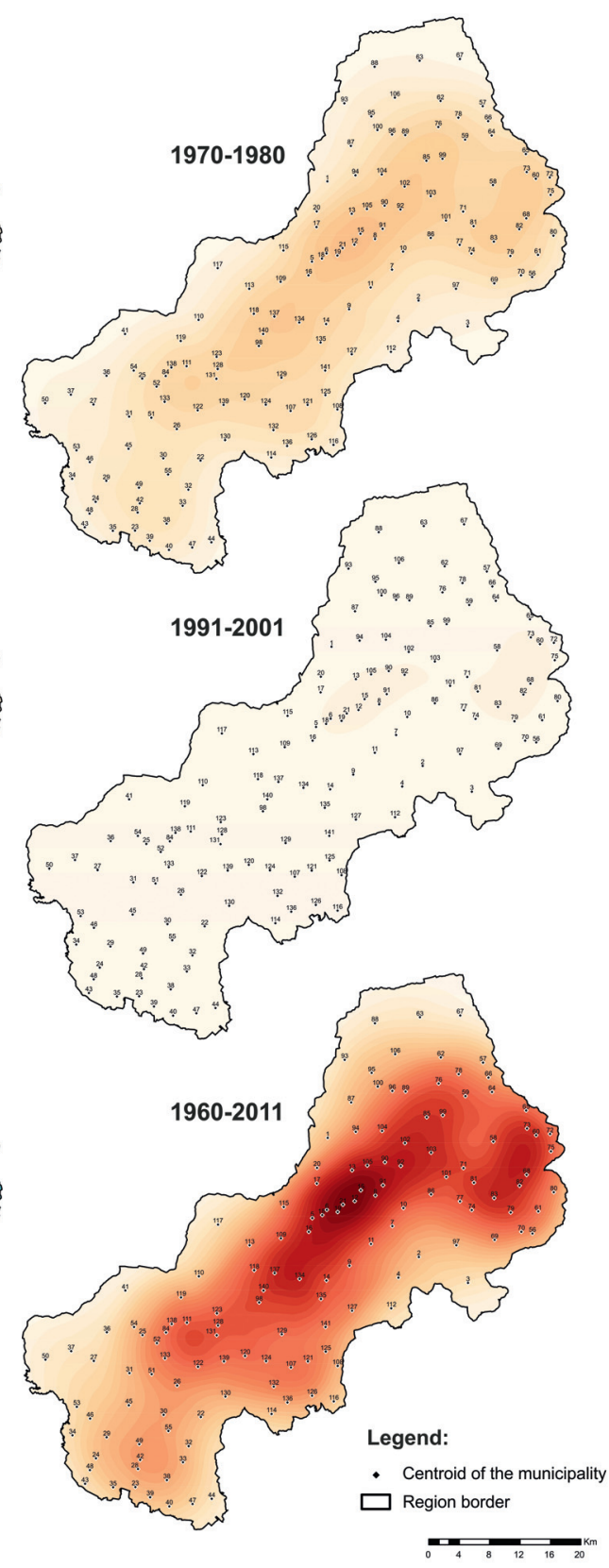

Kernel density (change population potential $/ \mathrm{km}^{2}$ in \%) 0.04

2.95

Figure 4. Change of population potential in the region Stredné Považie (1960-2011) 


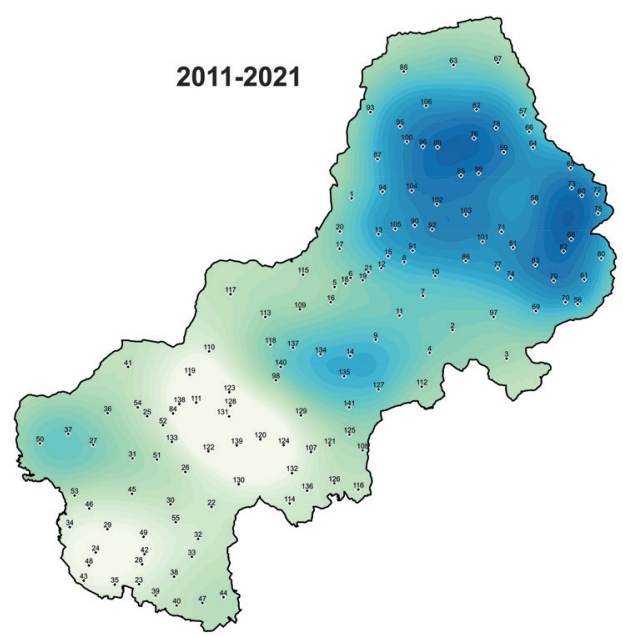

Kernel density (change population potential $/ \mathrm{km}^{2}$ in \%) $-0.12$ 0.03

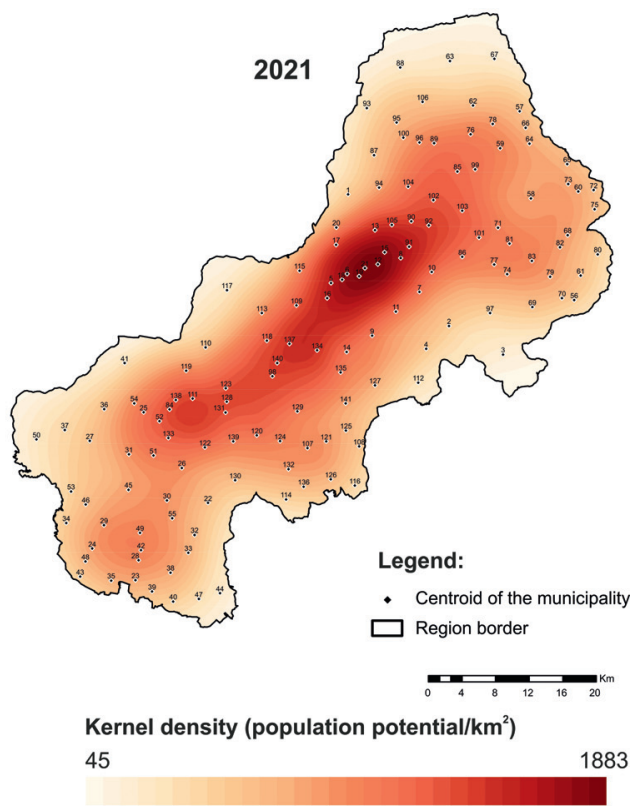

Figure 5. Projection of population potential in the region Stredné Považie to 2021

Since then an overall growth of population potential has been declining, reaching nearly 7\% between 1980-1991 and under 2\% during 1991-2001. This trend foreshadows that in the next few years, population potential will stabilize and even begin to decline. This happened already between 2001-2011, although only in a very slight form so far.

Further, we focus on revealing how the population potential will develop in the upcoming years. Therefore, a short-term projection to 2021 was processed (Fig. 5). It is obvious that the core area will probably retain its position as an area with the most significant population potential, as it was in the previous years. As far as the change in the next decade is concerned, value of population potential is supposed to decline, however, this decline should be less pronounced and more concentrated in the southern parts than in the previous decade.

\section{Discussion}

Spatial interaction, its structure, organization and intensity is attracting researchers across the scientific disciplines, including geography.
An effort to uncover the spatial context and incorporate space and scale into a way of thinking, is the privilege of geography (Rusnák et al. 2014). Population potential, as one of the interaction models, offers a great opportunity to study space and related network of interactions and thus to reveal certain patterns of territorial structure of population within a given geographical areas. As highlighted by Rich (1980), although all applications of the potential model share the same background, they differ from each other mainly in their interpretation, in the phenomena dealt with and in the purpose of their application. Thus, we may also recently encountered using population potential in different contexts. Faíña and López-Rodríguez $(2003,2006)$ focus on population potential in terms of level of development in EU, while emphasising differentiated factors operating and developing in time. In their later work they analyzed the effect of the EU enlargement processes on the population potential and its spatial pattern. An interesting insight provided Werner et al. (2014), who point out development of population potential in the context of land use 
change. The authors emanate from the definition of population potential as the possibility of interactions. In this sense, the value of the potential at a given point is a sensitive indicator of changes, including land use changes that occur in geographical space, particularly in urbanised areas.

Although traditionally understood model of population potential highlights mostly centripetal (gravity) forces, following its close conceptual, empirical and historical associations with the gravity model (Rich 1980), we acknowledge also importance of centrifugal forces (moving outward, pulling things, people, activities from the center). Even more when considering relations of industry, which as emphasised by Krugman (1999) tends to promote rather centrifugal effects, determined mainly by immobile factors (e.g. natural conditions), land rents or pure external diseconomies. However, at the same time he stresses that sometimes it is important to distinguish between centrifugal forces that push something out of a city and those that attract something towards the rural environment. The opposite is also applicable when analyzing centripetal forces. To a certain extend, manifestation of these forces can be recognized in our case study region as well. Centrifugal effect may be seen in the cartographic presentation, where the population potential does not concentrate only within urban areas, however, it is distributed in a rather continuous line along the surrounding rural areas in relative proximity to the urban centres. This trend points out how the localization of the manufacturing companies might have a centrifugal influence on population redistribution. This brings us to the acknowledgement of multifactoral approach to spatial distribution of population potential. Although gravity forces seems to dominate, other relevant factors, specific to individual regions which may create differences should not be neglected in such studies. In the case of the analyzed region Stredné Považie this can be interpreted as a combination of various specifics, or predispositions of the area. First of all, it can be considered as borderland region, thus peripheral in terms of geometrical aspects (cf. Leimgruber 2004). Secondly, according to its natural conditions it could be also recognized as mountain region (based on LFA categorization). Both such conditions tend to be generally related to some form of disadvantage (e.g. in terms of its distance and accessibility to areas central to the "mainstream of society"). This is closely connected to the widely applied core-periphery model. However, this kind of disadvantage is limited here predominantly by two factors that support each other. On the one hand, geographical location along the main transport corridor enables this region to "stay in touch" with the rest of the country due to its accessibility. On the other hand, log-term historical industrial tradition capitalizing on the proximity of transport connection. Unlike its counterparts with mountain and borderland nature in other parts of the country, these specifics have set a new direction for this region and its population redistribution. However, incidence of restrictive forces emanating from the peripheral and mountainous nature of the area can be recognized here as well, leaving peripheral, mostly remote rural areas areas characterized by rather scattered settlement, with the lowest population potential estimates.

The aforementioned considerations show multifaceted nature of population potential not only in the context of its interpretation but in terms of its usefulness and application, as well as the forces affecting it. It is therefore important to utilize this variety and to look at the model of population potential as an instrument suitable for the understanding of population redistribution in a broader geographical context.

\section{Conclusion}

In this article we attempt to analyze population potential and its impact on population redistribution in the case study region Stredné Považie from the long-term historical perspective. We point out some implications and key features in the changing nature of population potential in the last 50 years as well 
as insight into its future trajectory. We calculated population potential values and display them on maps which allows us to represent geographically the main lines of force in terms of population redistribution. Thus we obtain a realistic image of the territorial structure of population distribution and the spatial links and interaction taking place therein. Throughout the research we came across several interesting findings:

- Population potential in the region Stredné Považie was to a large extent influenced and formed by its historical specialization on heavy engineering and weaponry and following localization of industrial companies in this area, and this trend seems to persist.

- Specific geographical location of the region itself plays an important role here, since mountains surrounding the region act as a natural barrier to interactions which foreshadow the redistribution of population and the core of population potential to the central parts of the region.

- During the last 50 years, population potential was progressing and strengthening its position, thus nowadays represents a stable core of interactions in the regions seen as a more compact belt stretching through the region.

- An interesting conclusion can be drawn from the rural-urban perspective as well. Generally, as we move back from country or rural areas toward a great city there is a rise in potential because of the greater concentration of people there (Faína \& López-Rodríguez 2006). Although, within a given geographical space, identified core of population potential is in a close proximity to some industrial cities (e.g. Dubnica nad Váhom, Ilava, Trenčín), the highest value of population potential was recorded in the surrounding rural municipalities where many headquarters of the industrial companies are situated. Unlike their peripheral counterparts, mostly remote rural areas characterized by rather scattered settlement, rural areas in the central parts of the region have prerequisites for further development of population potential which may positively influence population redistribution in this areas.

In our study we point out only some of the key aspects related to the issue of population potential and its further implication for population redistribution. However, as declared by the literature review, population potential, and interaction potential as such, provide a wide scope for a scientific, especially geographical research. With this in mind, we see further possibility of extension of our research mostly in inclusion of interactions across the regional and even state borders, since the effects of external interactions could shape the population potential in another direction provided that the size of population and the strength of its potential outside the region would be significant. So far, reflection on whether and to what extent this might be relevant, remains only on a theoretical level.

\section{Acknowledgement:}

This study was prepared as a part of the research project APV-0018-12 "Human geography and demography interactions, nodes and contradictions in time-space network" as well as project UK/133/2015 "The study of perceptual marginality in rural areas in Slovakia". We would like to also thank the anonymous referees for their inspiring comments and suggestions on an earlier draft of this article.

Editors' note:

Unless otherwise stated, the sources of tables and figures are the authors', on the basis of their own research. 


\section{References}

Bezák A., 2011. Regionálna analýza. Študijný materiál. Bratrislava: Prírodovedecká fakulta Univerzity Komenského.

Binek J., Toušek V., Galvasová I., Vě̌̌ník A., Kunc J., Seidenglanz D., Halásek D., Řehák S., 2007. Venkovský prostor a jeho oživení. Brno: Georgetown.

Clark A.N., 1990. The Penguin dictionary of geography. London-New York: Penguin Books.

Condeço-Melhorado A., Reggiani A., GutiérREZ J., 2014. Accessibility and spatial interaction. Cheltenham-Northampton: Edward Elgar.

EDIEV D., 2001. Application of the demographic potential concept to understanding the Russian population history and prospects: 1897-2100. Demographic Research, vol. 4, art. 9, pp. 289-336.

EMPLOYMENT INSTITUTE, 2015. Region middle Vár river. http://www.iz.sk/en/projects/regions-ofslovakia/middle-vah-river [1 January 2015].

Faiña A., Lopez-RodríGuez J., 2003. Population potentials and development levels: Empirical findings in the European Union. ERSA Conference Papers, European Regional Science Association (ERSA).

Faí̃̃a A., López-Rodríguez J., 2006. European Union enlargement, European spatial development perspective and regional policy: Lessons from population potentials. Investigaciones regionales, vol. 9, pp. 3-21.

Geertman S.C.M., Ritsema Van ECK J., 1995. GIS and models of accessibility potential: An application in planning. International Journal of Geographical Information Systems, vol. 9, no. 1, pp. 67-80.

Goodall B., 1987. The Penguin dictionary of human geography. Harmondsworth-New York: Penguin Books.

Gregorová G., Kusenodvá D., 2005. Populačný potenciál Slovenska v roku 2001 [in:] J. Vaňo (ed.), Naša demografia - súčasnost a perspektívy: Zborník z konferencie: Smolenice 4-6.5.2005, Bratislava: Slovenská štatistická a demografická spoločnost', pp. 48-53.

GutiérRez J., 2001. Location, economic potential and daily accessibility: An analysis of the accessibility impact of the high speed line MadridBarcelona-French border. Journal of Transport Geography, vol. 9, no. 4, pp. 229-242.
HaLÁs M., 2002. Hranica a prihraničný región v geografickom priestore (teoretické aspekty). Geographia Slovaca, vol. 18, pp. 49-55

JeřábeK M., Dokoupil J., HavlíčEK, T., 2004. České pohraničíbariéra nebo prostor zprostréedkování? Praha: Academia.

Keeble D., Owens P.L., Thompson C., 1982. Regional accessibility and economic potential in the European Community. Regional Studies, vol. 16, no. 6, pp. 419-432.

KRUGMAN P., 1999. The role of geography in development. International Regional Science Review, vol. 22, no. 2, pp. 142-161.

LeIMgruber W., 2004. Between global and local: Marginality and marginal regions in the context of globalization and deregulation. Aldershot: Ashgate Publishing.

Linneker B.J., Spence N.A., 1992. Accessibility measures compared in an analysis of the impact of the M25 London Orbital Motorway on Britain. Environment and Planning A, vol. 24, no. 8, pp. 1137-1154.

Máliková L., KlobuČník M., BaČík V., Splšlak P., 2015. Socio-economic changes in the borderland of the Visegrad group (V4) countries. Moravian Geographical Reports, vol. 23, no. 2, pp. 26-37.

Michniak D., 2002. Dostupnost' ako geografická kategória a jej význam pri hodnotení územnosprávného členenia Slovenska. Bartislava: Slovenská akadémia vied [PhD thesis].

MLÁdeK J.,1993. Lokalizácia a rozvoj strojárskeho priemyslu na strednom Považí. Acta Facultatis Rerum Naturaluim Univeritatis Comenianae. Geographica, vol. 32, pp. 161-192.

MLÁDEK J., 1975. Typy priemyselných centier na Strednom Považí. Geografický časopis, vol. 27, no. 2, pp. 122-133.

PACIONE M. (ed.), 2014. Progress in rural geography. Oxon: Routledge.

POOLER J., 1987. Measuring geographical accessibility: A review of current approaches and problems in the use of population potentials. Geoforum, vol. 18, no. 3, pp. 269-289.

RICH D.C., 1980. Potential models in human geography. Norwich: Geo Abstracts.

Rusnák J., Ondoš S., Belušák L., 2014. Priestorové koncepty a poznávanie geografickej reality. Acta Geographica Universitatis Comenianae, vol. 58, no. 1, pp. 81-120. 
SteWART J.Q., 1941. An inverse distance variation for certain docial influences. Science, vol. 93, pp. 89-90.

SteWART J.Q., 1942. A measure of the influence of pupulation at a distance. Sociometry, vol. 5, no. 1, pp. 63-71.

Tobler W.R., 1970. A computer movie simulating urban growth in the Detroit region. Economic Geography, vol. 46, supp. 1, pp. 234-240.
VAŇO B., 2014. Populačný potenciál pre trh práce $v$ okresoch SR do roku 2030. Bratislava: Inštitút pre výskum práce a rodiny.

VYSTOUPIL J., 2003. Prognózy a modely v regionálním rozvoji. Brno: Ekonomicko-správní fakulta Masarykovy univerzity.

Werner P., Korcelli P., Kozubek E. 2014. Population potential as a modulator of land use changes in Poland's metropolitan areas. Quaestiones Geographicae, vol. 33, no. 2, pp. 37-50.
(C) Michal Klobučník • Lucia Máliková

(C) Geographia Polonica

(C) Institute of Geography and Spatial Organization

Polish Academy of Sciences • Warsaw • 2016
Article first received • November 2015

Article accepted • June 2016 